\title{
Can Fundamental Analysis Support Shareholder Value In A Transitional Market? Perspectives From Egypt
}

Tarek Ibrahim Eldomiaty, (Email: T.Eldomiaty@uaeu.ac.ae), UAE University, UAE

\begin{abstract}
This study examines the informativeness of fundamental financial information to three levels of shareholder value. In general, the results show that the fundamental financial information is quite informative to shareholders using the MB ratio as a measure of shareholder value. According to the sensitivity analysis, (1) the balance sheet items are not quite informative, (2) the income statement items are consistently informative to shareholders at the three classes, and (3) the financial ratios, as a form of co-integrated financial information, are quite informative to the high and low shareholder value classes. The results regarding the fundamental analysis indicate that (a) in the three levels of $M B$ firms, investors are concerned with the short-term horizon, $(b)$ in the low MB firms, the investors are concerned with the long-term horizon, $(c)$ in the high and low MB firms, the operating and total expenses are regarded as a capital investment, $(d)$ in the high MB firms, the trend is to finance operations using equity rather than debt financing, (e) profitability affects low $M B$ firms only rather than high and medium firms, $(f)$ in the high and medium MB firms, investors do not regard the elements related to firm's operations, $(g)$ in the low MB firms, investors are concerned with the effects of capital structure on firm's value although the results show that dividends have a reverse effect on firm's market value.
\end{abstract}

\section{INTRODUCTION}

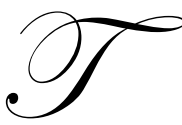

he literature on fundamental analysis utilized many aspects of financial information. The most common form is to use financial ratios that date back to over a century ago. Financial ratios have been providing the basic financial information to various decision makers. In this study, the true meaning of the fundamentals is examined using the most usable forms of fundamental financial information, which are (1) information extracted from firms' balance sheet, (2) information extracted from firms' income statement, and (3) integrated financial information that takes the form of wide range of financial ratios that have been examined in many studies in the literature. The major objective of this study is to explore to what extent the three types of fundamental financial information affect the shareholder value measured by the market-to-book ratio. The paper is organized as follows. Section II discusses the links between and among the fundamental financial information, stock market characteristics and shareholder value. Section III describes the research variables. Section IV discusses the data and methodology of the study. Section V describes the results and discusses the analysis respectively. Section VI concludes.

\section{FUNDAMENTAL ANALYSIS AND SHAREHOLDERS VALUE}

The literature on corporate financial fundamental analysis is one of the well-established fields of study in the finance theory. The literature has been trying to examine the interdisciplinary of three fields of study: financial management, corporate finance and investments. The common form of fundamental information is the financial ratios that have been used based on the assumption that they reflect (to some extent) events that have affected the firm's operations. These events include (a) those that occurred within the factor input markets and (b) those that occurred within the output markets of the firm. These events may be specific to a particular industry or maybe economy-wide events (Gonedes, 1973). As financial ratios are used extensively in the corporate financial reports, it is now a common 
understanding that if corporate financial reporting is to be adequately supportive of investment decision making, then clearly it must provide information useful to the formation of risk and return assessment (Farelly, et al., 1985). This study extends the relationship between the fundamental analysis and stock market characteristics to address one more dimension, which is shareholder value. Figure (1) shows links between firms and stock market characteristics, e.g., firms' earnings, stocks' returns, stocks' risks, and shareholder value. These links show clearly that shareholder value creation is to be considered an ultimate objective to the fundamental analysis.

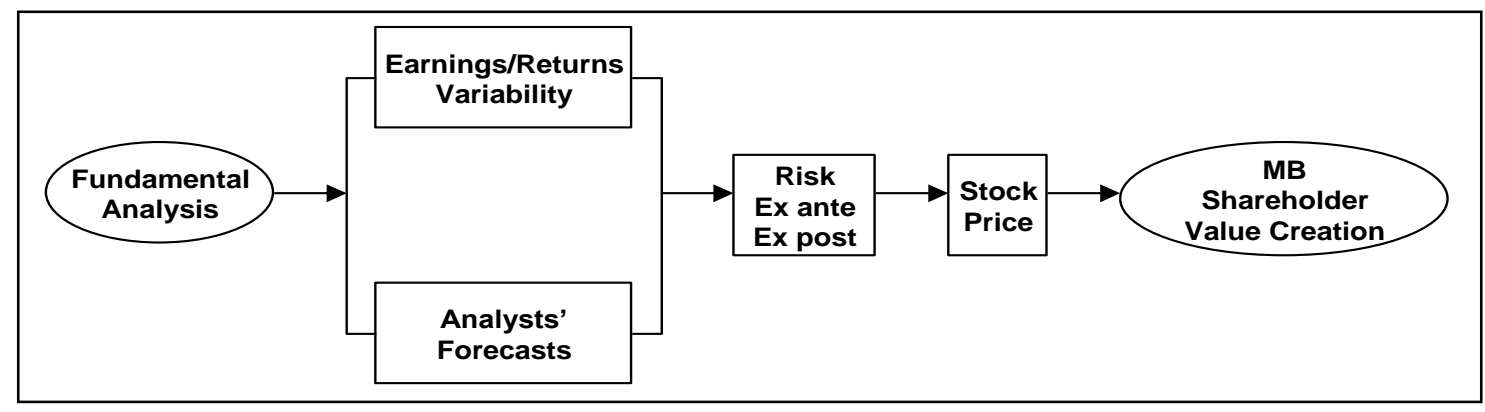

Figure : Fundamental Analysis, Stock Market Characteristics, And Shareholder Value Creation

The literature on the use of market-to-book ratio is extensive. The BM (or alternatively MB) ratio is the relationship between the book value of common equity to the market value of common equity. ${ }^{1}$ It is established in the theory of finance that the BM ratio reflects the relationship between firm's historical value of its assets and the economic value, or market assessment, of common equity. The market returns and information content of the BM ratios have also been studied using the inverse form: BM ratio. Brief and Lawson (1992) argue that the BM ratios explain the error term prevailing when accounting rates of return are used to estimate economic returns and IRR. Fairfield (1994) used the discounted cash flow valuation model and she showed that the BM ratio can be expressed as one plus the present value of discounted stream of future abnormal earnings divided by current book value. These findings are consistent with those reached by Lakonishok (1994) and La Porta (1996) that the BM ratios are significantly affected by the investors expectations. Over optimistic expectations about firm's earnings will lead to a drop in share prices when the actual earnings are released, thus resulting in high BM ratios. The vice versa is true in the case of stocks with low earnings expectations. Penman (1996) found that MB ratio reflects future profitability concluding that MB ratio should be 'nominated as the appropriate indicators of earnings growth' (Penman, 1996: p.256). Beaver and Ryan (2000) suggest that the BM components help to identify the rational pricing of expected ROE. Billings and Morton (2001) extended the work of Beaver and Ryan $(1996,2000)$ by decomposing the BM ratio concluding that the BM lag component explains most of the inverse relation between BM ratios and future returns. Their results suggest that the market anticipation of future earnings reflected in current BM ratios are not fully rational and predictable errors in those expectations result in predictable stock returns.

\section{RESEARCH VARIABLES AND PROXIES}

\section{Dependent Variable}

The dependent variable is the firm's market-to-book ratio. This ratio is recognized as a measure of shareholder value creation. In this study, the $\mathrm{M} / \mathrm{B}$ (rather than $\mathrm{B} / \mathrm{M}$ ) ratio is used as the dependent variable for two reasons: (1) it is a common measure of the value created to shareholders, and (2) the data used in this study does not contain negative values that can cause any interpretation problems.

\footnotetext{
${ }^{1}$ This relationship is typically expressed in the form of B/M ratio, rather than M/B ratio, for some practical reasons. As Beaver and Ryan (1996) indicate, the book-to-market form is used because the book value of common equity can take on small values or negative values. If book value is in the denominator of the ratio, problems of interpretation arise, while no particular problems arise if book values appear in the numerator. Therefore, the indications of $\mathrm{B} / \mathrm{M}$ ratio, or $\mathrm{M} / \mathrm{B}$ ratio, are the same when the book values are not discrete.
} 


\section{Independent Variables}

Primarily, the independent variables include the financial information that reflects firm's fundamentals. The literature on the use of financial fundamentals is extensive and does not include a consensus of the number, type and measurement of the financial information to be used. In this study, the financial information examined is classified into three categories, (a) Balance sheet information, (b) Income statement information, and (c) Integrated financial information (financial ratios). The items in the balance sheet and income statement are transformed into $\mathbf{L o g}_{\mathbf{1 0}}$ form and the financial ratios are measured in a standard ratio form. The author has surveyed the relevant literature and ended up with eight-nine ratios that are examined in this study. The ratios examined in this study were selected on the basis of:

- Popularity: the ratios that are commonly examined in the relevant literature and that are popularity in the 'Corporate Finance,' 'Financial Management' and 'Investment' textbooks that include financial ratio analysis as one of the main topics.

- $\quad$ Convenience: the ratios that are commonly mentioned in (or easily calculated using) corporate reports and/or financial analysts reports. ${ }^{2}$ This criterion allows examining the extent to which the on-reach financial ratios reflect corporate fundamentals and, therefore, affect investors behavior

- Scope: the financial ratios are basically corporate rather than industry ratios.

- $\quad$ Availability: the financial ratios are available for all firms included in the study for seven years.

\section{DATA AND METHODOLOGY}

\section{Data}

The data used in this study is extracted form many sources. The income statement and balance sheet data are from the firms' annual reports. The firms' market value, MB ratio, PE ratio, and industry averages are published by Kompass Egypt Financial Year Book (Fiani \& Partners) and the stock market publications in Egypt. The interest rate data is published by the IMF: International Financial Statistics. The data covers five years 1999-2003. The total number of firms included in the study is 99 firms. Firms were selected based on two criteria. First, the non-financial firms amongst the 100 actively trading firms in Egypt stock market. Second, the non-financial firms amongst the 100 firms with the highest market value.

\section{Methodology}

\section{Estimation}

The methodology examines the effects of the three types of financial information on the firm's MB ratios that are classified into three levels: High, medium and low MB. The properties of the partial adjustment model capture the effects under consideration. The general estimating equation of the partial adjustment autoregressive model takes the form that follows. ${ }^{3}$

$$
\begin{aligned}
& \mathbf{y}_{\mathrm{tk}}=\alpha_{\mathrm{k}}+\beta_{\mathrm{k}} \mathbf{y}_{\mathrm{t}-1, \mathrm{k}}+\sum_{\mathrm{i}=1}^{\mathrm{k}} \beta_{\mathrm{ik}} \mathbf{X}_{\mathrm{itk}}+\varepsilon_{\mathrm{tk}} \\
& \text { where } \mathrm{t}=1, \ldots, \mathrm{n} \\
& \mathrm{k}=\text { number of firms in each group }
\end{aligned}
$$

\footnotetext{
${ }^{2}$ The financial ratios commonly discussed in Financial Management textbooks are also considered a good basis.

${ }^{3}$ For more detailed discussion about the structures of partial adjustment models, see, Kennedy (1998, pp.143-156) and Greene (2000, pp.720724.
} 
Sensitivity Analysis (Robustness of the Estimates)

In the literature of fundamental analysis, selective reporting is highly likely given the very large number of potential regressors. For this, Extreme Bound Analysis (EBA) avoids the pitfalls of selective reporting by directly incorporating prior information and following a systematic approach to testing the fragility of coefficient estimates. As indicated by Leamer (1983, 1985), Leamer and Leonard (1983) and Levine and Renelt (1992), the EBA uses equation that takes the form:

$$
\boldsymbol{Y}=\beta_{i} \mathbf{I}+\beta_{m} \boldsymbol{M}+\beta_{z} \boldsymbol{Z}+\boldsymbol{u}
$$

Where $\boldsymbol{Y}=$ The proxy for shareholder value (MB ratio).

$\mathbf{I}=\quad$ Set of variables always included in the regression. These are the items of the balance sheet, the items of the income statement and the financial ratios included in this study.

$\boldsymbol{M}=$ The variables of interest. In this study, these variables refer to the speed of adjusting shareholder value to a target level in the partial adjustment model.

$\boldsymbol{Z}=\quad$ Subset of variables chosen from a pool of variables identified by past studies as potentially important explanatory variables that affect the dependent variable. In this study, these variables refer to (a) sources and used of financing in firms' balance sheets, (b) operating and financing activities in firms' income statements, and (c) the common classification of financial ratios as liquidity, assets efficiency, expense control, debt levels and profitability.

The degree of confidence that one can have in the partial correlation between the $\boldsymbol{Y}$ and $\boldsymbol{M}$ variables can be inferred from the extreme bounds on the coefficient $\beta_{m}$. If $\beta_{m}$ remains significant and of the same sign at the extreme bounds, then one can maintain a fair amount of confidence in that partial correlation. In such a case, we refer to the coefficient estimate as "Robust,' otherwise, it is "Fragile."

\section{RESULTS AND DISCUSSION}

According to the methodology of this paper, the three types of financial information are regressed against the MB ratios. The results are divided into two parts, the first discusses the estimates of the regression coefficients and the second discusses the robustness (sensitivity analysis) of the estimates.

\section{Informativeness of Balance Sheet Information and Shareholder Value}

This is examined by regressing the financial information mentioned in firm's balance sheet against the three levels of MB ratio. Table 1 shows the regression results.

Regarding the speed of adjustment $\log _{10}(\text { Market - to - Book })_{t-1}$, the balance sheet items for high MB firms help adjust the MB ratio to a target level (speed of adjustment $=0.39)$ than for the case of low MB firms $(0.008)$. This is an expected result since high MB firms should be concerned with showing to the stock market that they are capable of maintaining and providing value to their investors. The coefficient of speed of adjustment for the medium MB firms is not statistically significant. As for the high MB firms, the results show that the coefficient of cash is positive and statistically significant, indicating an unexpected result. As a financial principle, the amount of cash is a useless investment. The other statistically significant coefficients are those of the construction in progress and longterm investment. Their negative signs indicate that investors do not appreciate increases in these items.

The other item with statistically significant coefficient is the book value per share with negative sign, which is expected with the MB ratio. The results for the medium MB firms show reasonable results. Among the statistically significant coefficient, the inventory and short-term investment are associated with positive sign indicating the investors' appreciation to the short-term horizon taken into account that the inventory is another form of the short- 
Table 1: The Content Of Balance Sheet Information And Shareholder Value

Regression coefficients for the information content of the balance sheet items. The dependent variable is the market-to-book ratio. The t-statistics are shown between brackets. The multicollinearity was examined before carrying out the regression analysis, and variables associated with VIF $\geq 5$ are excluded. Outliers are detected and excluded as well. The heteroskedastic effects are corrected using the White's HCSEC, which improves the significance of the OLS estimates.

\begin{tabular}{|c|c|c|c|c|}
\hline \multirow{2}{*}{ Variables } & \multirow{2}{*}{ Abbreviations } & \multicolumn{3}{|c|}{ Firm's Market-to-Book Ratio } \\
\hline & & High & Medium & Low \\
\hline $\begin{array}{l}\text { Dependent: } \\
\log _{10}(\text { Market }- \text { to }- \text { Book })_{t}\end{array}$ & $\left(\log _{10} \mathrm{MB}\right)_{\mathrm{t}}$ & & & \\
\hline Independents: & Constant & 0.31 & -0.001 & 0.002 \\
\hline $\log _{10}(\text { Market - to - Book })_{\mathrm{t}-1}$ & $\left(\log _{10} M B\right)_{t-1}$ & $\begin{array}{c}0.39 \\
(6.24)^{* * * *} \\
\end{array}$ & $\begin{array}{c}0.0001 \\
(0.4) \\
\end{array}$ & $\begin{array}{c}0.008 \\
(2.15)^{* * *} \\
\end{array}$ \\
\hline Cash and Equivalents & $\log _{10}$ Cash & $\begin{array}{c}0.14 \\
(1.88)^{*}\end{array}$ & & $\begin{array}{c}-0.00005 \\
(-0.46) \\
\end{array}$ \\
\hline Receivables & $\log _{10} \operatorname{Rec}$ & $\begin{array}{c}0.11 \\
(0.79) \\
\end{array}$ & & \\
\hline Inventory & $\log _{10}$ Inven & $\begin{array}{c}0.04 \\
(0.44) \\
\end{array}$ & $\begin{array}{c}0.001 \\
(3.14)^{\text {***** }}\end{array}$ & $\begin{array}{c}0.00002 \\
(1.38)\end{array}$ \\
\hline Short-Term Investment & $\log _{10}$ STI & $\begin{array}{c}-0.03 \\
(-0.91) \\
\end{array}$ & $\begin{array}{c}0.0001 \\
(2.62)^{\text {****** }}\end{array}$ & $\begin{array}{l}0.001 \\
(1.33) \\
\end{array}$ \\
\hline Construction in Progress & $\log _{10}$ CIP & $\begin{array}{c}-0.09 \\
(-2.22)^{* *} \\
\end{array}$ & & \\
\hline Long-Term Investment & $\log _{10} \mathrm{LTI}$ & $\begin{array}{c}-0.08 \\
(-2.41)^{* *}\end{array}$ & $\begin{array}{c}-0.0001 \\
(-2.6)^{* * *}\end{array}$ & $\begin{array}{c}0.002 \\
(1.65)^{*}\end{array}$ \\
\hline Accounts Payables & $\log _{10} \mathrm{AP}$ & & & $\begin{array}{c}-0.0005 \\
(-0.4)\end{array}$ \\
\hline Long-Term Debt & $\log _{10} \mathrm{LTD}$ & & $\begin{array}{c}0.00001 \\
(0.48)\end{array}$ & $\begin{array}{l}-0.001 \\
(-1.11) \\
\end{array}$ \\
\hline Retained Earnings & $\log _{10} R E$ & & & $\begin{array}{l}0.001 \\
(0.56) \\
\end{array}$ \\
\hline $\begin{array}{l}\text { Total Current Liabilities \& Stockholder } \\
\text { Equity }\end{array}$ & $\log _{10}$ CLSE & & $\begin{array}{l}-0.0002 \\
(-2.19)^{* *}\end{array}$ & \\
\hline Number of Shares Outstanding & $\log _{10}$ NSO & & $\begin{array}{c}-1.0002 \\
(-3668.6)^{* * *}\end{array}$ & $\begin{array}{c}-0.98 \\
(-122.9)^{\text {**** }}\end{array}$ \\
\hline Market Value of Shares Outstanding & $\log _{10} \mathrm{MV}$ & & $\begin{array}{c}0.99 \\
(3541.23)^{\text {**** }} \\
\end{array}$ & $\begin{array}{c}0.98 \\
(118.9)^{* * *} \\
\end{array}$ \\
\hline Book Value Per Share & $\log _{10}$ BVPS & $\begin{array}{c}-0.52 \\
(-3.26)\end{array}{ }^{\text {**** }}$ & $\begin{array}{c}-1 \\
(3117.06)\end{array}$ & $\begin{array}{c}-0.99 \\
(-147.5)\end{array}{ }^{\text {*** }}$ \\
\hline Net working Capital & $\log _{10}$ NWC & $\begin{array}{l}0.002 \\
(0.08) \\
\end{array}$ & $\begin{array}{c}0.00002 \\
(0.64)\end{array}$ & $\begin{array}{l}0.001 \\
(0.72)\end{array}$ \\
\hline \multicolumn{2}{|c|}{$N$} & 119 & 127 & 320 \\
\hline \multicolumn{2}{|c|}{$\begin{array}{r}\text { F statistics } \\
(\text { Sig } F) \\
\end{array}$} & $7.78^{* * * *}$ & $3496203^{\text {**** }}$ & $17323.5^{* * * *}$ \\
\hline \multicolumn{2}{|c|}{$\bar{R}^{2}$} & 0.34 & 0.99 & 0.99 \\
\hline \multicolumn{2}{|c|}{$\mathrm{D}-\mathrm{W}$ test } & $1.95^{* * * * * *}$ & $1.94^{\text {******** }}$ & $1.99^{* * * * *}$ \\
\hline \multicolumn{2}{|c|}{ Theil Inequality Coefficient } & 0.33 & 0.001 & 0.02 \\
\hline
\end{tabular}




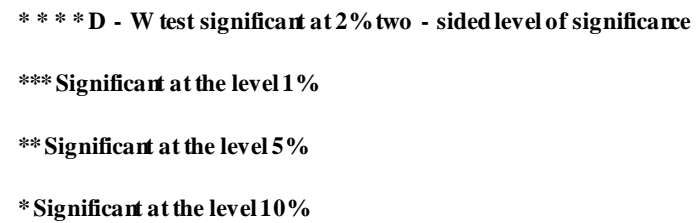

term investments. This result is validated by the negative and statistically significant coefficient of the long-term investment, which indicates that investors do not appreciate the long-term horizon.

The positive and statistically significant coefficient of the market value of shares outstanding is expected as long as investors are concerned with monitoring the value of their investments. The negative and statistically significant coefficient of the book value per share is expected to its relationship with the MB ratio. As for the low MB firms, the results show somewhat different coefficients. What is noticeable is that the investors in those firms are concerned with the long-term horizon shown by the positive and statistically significant coefficient of long-term investments. The positive and statistically significant coefficient of market value of shares outstanding indicates the investors' concern with the value of their investment. The negative and statistically significant coefficient of the number of shares outstanding indicates that the investors do not appreciate equity financing since those firms are categorized with low MB ratio. The same is true for the medium MB firms. It is worth to note that, for the medium and low MB firms, the explanatory power of the regression equations is extremely high (0.99), indicating the investors' high concern with every category of financial information that helps monitor the financial health of their investments.

\section{Informativeness Of Income Statement Information And Shareholder Value}

This is examined by regressing the financial information mentioned in firm's income statement against the three levels of MB ratio. Table 2 shows the regression results.

Regarding the speed of adjustment, the results show that all coefficient of $\left(\log _{10} M B\right)_{t-1}$ for the three levels are positive and statistically significant. The most concerned firms with adjusting MB to a target level are the low MB firms that are associated with the highest speed of adjustment (0.80), followed by the firms with medium MB ratio (0.42), then the firms with high MB ratios (0.35). As for the latter firms, the results show that three items are positive and statistically significant items. These items are the selling, general and administrative expenses, other revenues, and net income. As for the first item, despite the fact that its effect could be negative as it reduces the firm's earnings power, the marketing literature provides some support to the positive sign reported in this study as long as that type of expenses is regarded as a form of capital investment, i.e., selling expenses support sales activities. The other two positive coefficients are considered good indicators to the firm's earning power. The negative and statistically significant coefficient of interest expenses indicates that the investors do not appreciate debt financing. As for the medium MB firms, the results indicate that the only statistically significant item is the net income with its associated positive coefficient. It seems that as the MB is getting lower, the investors become more concerned with the firm's earnings power. As for the low MB firms, the results show that there are three positive and statistically significant items. These items are provisions, total expenses, and other revenues. The positive sign of the provisions indicates the investors concern with the firm's financial safety taking into account that their investments are not very valued in the stock market. The argument for the total expenses is the same as in the case of the high MB firms; that is taken as an indication to the firm's concern toward supporting its operations. The positive sign of the coefficient of other revenues indicates the investors concern with the firm's sources of earnings especially that these firms are not highly valued in the market. The explanatory power of the three regressions models show that the results for the low MB ratio firms (associated with the highest adjusted $R^{2}$ ) are more indicative, followed by the medium MB firms, then the high MB firms. 
Table 2: The Content Of Income Statement Information And Shareholder Value ${ }^{4}$

Regression coefficients for the information content of the income statement items. The dependent variable is the market-to-book ratio. The t-statistics are shown between brackets. The multicollinearity was examined before carrying out the regression analysis, and variables associated with VIF $\geq 5$ are excluded. Outliers are detected and excluded as well. The heteroskedastic effects are corrected using the White's HCSEC, which improves the significance of the OLS estimates.

\begin{tabular}{|c|c|c|c|c|}
\hline \multirow{2}{*}{ Variables } & \multirow{2}{*}{ Abbreviations } & \multicolumn{3}{|c|}{ Firm's Market-to-Book Ratio } \\
\hline & & High & Medium & Low \\
\hline $\begin{array}{l}\text { Dependent: } \\
\log _{10}(\text { Market - to - Book })_{\mathrm{t}}\end{array}$ & $\left(\log _{10} \mathrm{MB}\right)_{\mathrm{t}}$ & & & \\
\hline Independents: & Constant & -1.14 & -0.02 & -0.18 \\
\hline $\log _{10}(\text { Market - to }- \text { Book })_{\mathrm{t}-1}$ & $\left(\log _{10} \mathrm{MB}\right)_{\mathrm{t}-1}$ & $\begin{array}{c}0.35 \\
(5.58)^{* * * *} \\
\end{array}$ & $\begin{array}{c}0.42 \\
(8.77)^{\text {**** }}\end{array}$ & $\begin{array}{c}0.80 \\
(20.67)^{\text {**** }}\end{array}$ \\
\hline Selling, General, and Administrative Expenses & $\log _{10} \mathrm{SGAE}$ & $\begin{array}{c}0.25 \\
(2.54)^{\text {****** }} \\
\end{array}$ & $\begin{array}{l}-0.03 \\
(-0.5) \\
\end{array}$ & $\begin{array}{l}0.004 \\
(0.15) \\
\end{array}$ \\
\hline Provisions & $\log _{10}$ Prov & $\begin{array}{c}0.02 \\
(1.05)\end{array}$ & $\begin{array}{c}0.01 \\
(1.04)\end{array}$ & $\begin{array}{c}0.015 \\
(2.11)^{* * *}\end{array}$ \\
\hline Total Expenses & $\log _{10} \mathrm{TE}$ & & & $\begin{array}{c}0.014 \\
(2.25)^{* *}\end{array}$ \\
\hline Earnings Before Interest \& Taxes & $\log _{10}$ EBIT & & $\begin{array}{l}-0.02 \\
(-0.9) \\
\end{array}$ & \\
\hline Investment Income & $\log _{10}$ Invin & & $\begin{array}{l}0.002 \\
(0.16)\end{array}$ & $\begin{array}{l}-0.005 \\
(-0.48) \\
\end{array}$ \\
\hline Interest Income & $\log _{10}$ Intin & $\begin{array}{l}0.02 \\
(0.7) \\
\end{array}$ & $\begin{array}{l}0.007 \\
(0.44) \\
\end{array}$ & $\begin{array}{l}0.002 \\
(0.19) \\
\end{array}$ \\
\hline Interest Expenses & $\log _{10}$ Intexp & $\begin{array}{c}-0.06 \\
(-2.22)^{* *} \\
\end{array}$ & $\begin{array}{c}-0.02 \\
(-1.32) \\
\end{array}$ & $\begin{array}{c}-0.01 \\
(-1.56) \\
\end{array}$ \\
\hline Other Revenues & $\log _{10} \mathrm{OR}$ & $\begin{array}{c}0.11 \\
(2.76)^{* * * *} \\
\end{array}$ & $\begin{array}{c}0.02 \\
(-0.005) \\
\end{array}$ & $\begin{array}{c}0.02 \\
(2.06)^{* *} \\
\end{array}$ \\
\hline Extraordinary Revenues & $\log _{10}$ EXR & & $\begin{array}{c}0.01 \\
(0.84) \\
\end{array}$ & \\
\hline Extraordinary Expenses & $\log _{10}$ EXEX & $\begin{array}{c}-0.04 \\
(-1.15)\end{array}$ & $\begin{array}{l}-0.0001 \\
(-0.004)\end{array}$ & $\begin{array}{c}-0.0002 \\
(-0.02) \\
\end{array}$ \\
\hline Taxes & $\log _{10}$ TAX & & $\begin{array}{c}-0.01 \\
(-0.95)\end{array}$ & $\begin{array}{c}0.01 \\
(0.86) \\
\end{array}$ \\
\hline Net Income & $\log _{10} \mathrm{NI}$ & $\begin{array}{c}0.11 \\
(1.69)^{*}\end{array}$ & $\begin{array}{c}0.12 \\
(1.91)^{*}\end{array}$ & $\begin{array}{c}0.01 \\
(0.83) \\
\end{array}$ \\
\hline \multicolumn{2}{|c|}{$N$} & 117 & 129 & 308 \\
\hline \multicolumn{2}{|l|}{$\begin{array}{r}\text { F statistics } \\
(\text { Sig F }) \\
\end{array}$} & $10.54^{* * * *}$ & $15.54^{\text {**** }}$ & $150.45^{\text {***** }}$ \\
\hline \multicolumn{2}{|l|}{$\bar{R}^{2}$} & 0.40 & 0.57 & 0.84 \\
\hline \multicolumn{2}{|l|}{$\mathrm{D}-\mathrm{W}$ test } & $2.23^{\text {******* }}$ & $2.11^{\text {****** }}$ & $1.73^{\text {******** }}$ \\
\hline \multicolumn{2}{|l|}{ Theil Inequality Coefficient } & 0.29 & 0.21 & 0.20 \\
\hline
\end{tabular}

$4 * * * *$ D-W test significant at $2 \%$ two-sided level of significance

$* * *$ Significant at the level $1 \%$

** Significant at the level $2 \%$

* Significant at the level $5 \%$ 


\section{Informativeness of Financial Ratios Information and Shareholder Value}

This is examined by regressing the information content of the financial ratios (all extracted from the balance sheet and income statement) against the three levels of MB ratio. Table 3 shows the regression results.

Table 3: The Content Of Financial Ratios Information And Shareholder Value

Regression coefficients for the information content of the financial ratios. The dependent variable is the market-to-book ratio. The t-statistics are shown between brackets. The multicollinearity was examined before carrying out the regression analysis, and variables associated with VIF $\geq 5$ are excluded. Outliers are detected and excluded as well. The heteroskedastic effects are corrected using the White's HCSEC, which improves the significance of the OLS estimates.

\begin{tabular}{|c|c|c|c|c|}
\hline \multirow{2}{*}{ Variables } & \multirow{2}{*}{ Abbreviations } & \multicolumn{3}{|c|}{ Firm's Market-to-Book Ratio } \\
\hline & & High & Medium & Low \\
\hline $\begin{array}{l}\text { Dependent: } \\
(\mathrm{M} \text { arket - to - Book })_{\mathrm{t}}\end{array}$ & $\mathrm{MB}_{\mathrm{t}}$ & & & \\
\hline Independents: & Constant & -3.51 & 5.43 & 0.59 \\
\hline$(\text { Market - to - Book })_{t-1}$ & $\mathrm{MB}_{\mathrm{t}-1}$ & $\begin{array}{c}0.25 \\
(4.42)^{* * *} \\
\end{array}$ & $\begin{array}{c}0.18 \\
(2.07)^{* *} \\
\end{array}$ & $\begin{array}{c}0.62 \\
(14.45)^{* * *} \\
\end{array}$ \\
\hline Inventory/Current Assets & INVCA & $\begin{array}{c}0.69 \\
(0.22)\end{array}$ & & \\
\hline Accounts Receivables/Current Assets & ARCA & & & $\begin{array}{c}-0.13 \\
(-0.92) \\
\end{array}$ \\
\hline Quick Ratio & QR & & $\begin{array}{c}-3.68 \\
(-2.35)^{* *}\end{array}$ & $\begin{array}{c}0.12 \\
(1.12) \\
\end{array}$ \\
\hline Current Ratio & $\mathrm{CR}$ & & & $\begin{array}{c}0.03 \\
(0.72)\end{array}$ \\
\hline Total Liabilities/Net Worth & TLNW & & & $\begin{array}{l}0.005 \\
(0.46)\end{array}$ \\
\hline Cash Ratio & CASHR & $\begin{array}{c}2.08 \\
(2.07)^{\text {** }} \\
\end{array}$ & & $\begin{array}{c}0.16 \\
(1.89)^{*} \\
\end{array}$ \\
\hline Net Working Capital/Total Assets & NWCTA & $\begin{array}{c}-0.73 \\
(-0.12) \\
\end{array}$ & $\begin{array}{c}8.99 \\
(2.92)^{\text {*** }} \\
\end{array}$ & \\
\hline Interval Measure & IM & $\begin{array}{l}-0.0002 \\
(-0.004) \\
\end{array}$ & & $\begin{array}{c}-0.0004 \\
(-1.17)^{* * *}\end{array}$ \\
\hline$($ Cash + Receivables $) /$ Expenditure for Operations & CRTE & $\begin{array}{l}-0.002 \\
(-0.33) \\
\end{array}$ & $\begin{array}{c}-0.05 \\
(-1.73)^{*}\end{array}$ & $\begin{array}{c}0.002 \\
(1.86)^{*}\end{array}$ \\
\hline Total Assets Turnover & TAT & $\begin{array}{c}-2.21 \\
(-1.42) \\
\end{array}$ & & $\begin{array}{c}0.08 \\
(1.87)^{*} \\
\end{array}$ \\
\hline Fixed Assets Turnover & FAT & & & $\begin{array}{c}0.002 \\
(3.13)^{* * *} \\
\end{array}$ \\
\hline Inventory Turnover on Cost of Goods Sold & INVC & & & $\begin{array}{l}0.004 \\
(0.88) \\
\end{array}$ \\
\hline Inventory Ratio & INVR & $\begin{array}{l}-1.41 \\
(-0.27)\end{array}$ & $\begin{array}{c}-6.8 \\
(-2.08)^{* *}\end{array}$ & $\begin{array}{c}0.04 \\
(0.21)\end{array}$ \\
\hline Days in Period/Inventory Turnover & DINV & & $\begin{array}{l}-0.001 \\
(-0.48)\end{array}$ & \\
\hline Accounts Receivables Turnover & ART & & $\begin{array}{c}0.01 \\
(0.77) \\
\end{array}$ & \\
\hline Accounts Payables Turnover & APT & & & $\begin{array}{l}-0.0003 \\
(-0.31) \\
\end{array}$ \\
\hline
\end{tabular}




\begin{tabular}{|c|c|c|c|c|}
\hline Net Working Capital Turnover & NWCT & $\begin{array}{c}0.0002 \\
(0.4)\end{array}$ & $\begin{array}{l}-0.004 \\
(-1.02)\end{array}$ & $\begin{array}{c}-0.0003 \\
(-1.37)\end{array}$ \\
\hline Working Capital/Cash Flow & WCCF & $\begin{array}{c}-0.06 \\
(-3.17)^{\text {*** }}\end{array}$ & & $\begin{array}{c}-0.001 \\
(-3.37)^{\text {**** }}\end{array}$ \\
\hline Accounts Payables/Annual Net Sales & APS & & & $\begin{array}{c}0.008 \\
(0.21) \\
\end{array}$ \\
\hline Net Worth/Fixed Assets & NWFA & $\begin{array}{l}0.004 \\
(0.06) \\
\end{array}$ & & \\
\hline Assets Annual Growth & AG & & $\begin{array}{c}0.59 \\
(1.35) \\
\end{array}$ & $\begin{array}{c}0.11 \\
(7.34)^{\text {**** }}\end{array}$ \\
\hline Sales Annual Growth & SG & $\begin{array}{c}-0.15 \\
(-0.33) \\
\end{array}$ & $\begin{array}{c}-0.12 \\
(-0.99)\end{array}$ & $\begin{array}{c}0.07 \\
(2.81)^{\text {*** }}\end{array}$ \\
\hline Cost of Sales/Net Sales & COGSS & & $\begin{array}{c}-4.39 \\
(-1.47) \\
\end{array}$ & \\
\hline (Operating Expenses + Cost of Sales)/Net Sales & ES & $\begin{array}{c}2.97 \\
(1.91)^{*}\end{array}$ & & \\
\hline Operating Expenses/Gross Margin & OEGM & & $\begin{array}{l}-1.11 \\
(-1.11)\end{array}$ & $\begin{array}{c}0.01 \\
(1.93)^{\text {** }}\end{array}$ \\
\hline Operating Expenses/Total Assets & OEA & $\begin{array}{l}10.11 \\
(1.09) \\
\end{array}$ & $\begin{array}{c}9.36 \\
(1.33) \\
\end{array}$ & \\
\hline Ratio of Investment/Earnings & IE & $\begin{array}{c}0.04 \\
(2.07)^{* *}\end{array}$ & $\begin{array}{c}-0.01 \\
(-0.43) \\
\end{array}$ & \\
\hline Current Liabilities/Working Capital & CLWC & $\begin{array}{l}-0.51 \\
(-0.6)\end{array}$ & & \\
\hline Assets/Equity & $\mathrm{AE}$ & $\begin{array}{c}0.20 \\
(4.24)^{* * *} \\
\end{array}$ & & \\
\hline Short-Term Debt/Total Debt & STDTD & $\begin{array}{c}4.93 \\
(1.96)^{* *}\end{array}$ & $\begin{array}{c}4.17 \\
(1.18)\end{array}$ & $\begin{array}{l}0.002 \\
(0.03)\end{array}$ \\
\hline Times Interest Earned & TIE & $\begin{array}{c}0.04 \\
(1.91)^{*}\end{array}$ & & \\
\hline Earning Before Interest \& Taxes/Fixed Charges & EBITFC & $\begin{array}{c}0.14 \\
(1.41)\end{array}$ & $\begin{array}{c}0.01 \\
(0.35)\end{array}$ & \\
\hline Times Interest Covered by Cash Flow & CFI & $\begin{array}{c}-0.05 \\
(-2.26)^{* *} \\
\end{array}$ & & \\
\hline$($ Net Income + Interest $) /$ Interest & NII & & $\begin{array}{c}0.003 \\
(2.48)^{* * *}\end{array}$ & $\begin{array}{c}0.0001 \\
(0.45) \\
\end{array}$ \\
\hline Net Worth/Total Debt & NWD & & $\begin{array}{c}-0.51 \\
(-0.45)\end{array}$ & $\begin{array}{c}-0.15 \\
(-1.76)^{*}\end{array}$ \\
\hline Operating Leverage & OL & & & $\begin{array}{c}-0.02 \\
(-0.76)\end{array}$ \\
\hline Long-Term Debt/Net Worth & LTDNW & $\begin{array}{l}0.18 \\
(0.9)\end{array}$ & $\begin{array}{c}0.83 \\
(0.97)\end{array}$ & $\begin{array}{l}-0.004 \\
(-0.08) \\
\end{array}$ \\
\hline Fixed Assets/Total Assets & FATA & $\begin{array}{c}-1.95 \\
(-0.97)\end{array}$ & $\begin{array}{l}-1.28 \\
(-0.81)\end{array}$ & $\begin{array}{l}0.17 \\
(0.7)\end{array}$ \\
\hline Return On Net Worth & RONW & $\begin{array}{c}-1.07 \\
(-1.66)^{*}\end{array}$ & & \\
\hline Return On Assets & ROA & & $\begin{array}{c}5.15 \\
(1.59) \\
\end{array}$ & \\
\hline Cash Flow Per Share & CFPS & $\begin{array}{c}0.07 \\
(8.41)^{* * * *}\end{array}$ & $\begin{array}{c}0.02 \\
(1.74)\end{array}$ & $\begin{array}{l}0.001 \\
(1.29) \\
\end{array}$ \\
\hline Cash Flow/Long-Term Debt & CFLTD & $\begin{array}{l}0.006 \\
(0.32) \\
\end{array}$ & & $\begin{array}{c}-0.0004 \\
(-0.04) \\
\end{array}$ \\
\hline
\end{tabular}




\begin{tabular}{|c|c|c|c|c|}
\hline Price-Earnings Ratio & $\mathrm{PE}$ & $\begin{array}{c}0.16 \\
(8.52)^{\text {**** }}\end{array}$ & & \\
\hline Price-Cash Flow Ratio & $\mathrm{PCF}$ & & $\begin{array}{c}0.11 \\
(3.67)^{\text {*** }}\end{array}$ & $\begin{array}{c}0.003 \\
(1.14)\end{array}$ \\
\hline Net Profit/Pretax Profit & TB & & $\begin{array}{c}1.18 \\
(0.57) \\
\end{array}$ & \\
\hline Pretax Profit/Earnings Before Interest \& Taxes & IB & $\begin{array}{c}0.43 \\
(0.63)\end{array}$ & & $\begin{array}{c}0.01 \\
(1.85)^{*}\end{array}$ \\
\hline Earnings Before Interest \& Taxes/Net Sales & EBITS & $\begin{array}{c}-3.85 \\
(-1.69)\end{array}$ & $\begin{array}{c}-5.52 \\
(-1.91)^{*}\end{array}$ & $\begin{array}{c}-0.24 \\
(-1.84)^{*}\end{array}$ \\
\hline Market Value Added & MVA & $\begin{array}{c}4.39 \\
(1.41) \\
\end{array}$ & $\begin{array}{c}0.0001 \\
(3.82)^{* * *}\end{array}$ & $\begin{array}{c}0.0005 \\
(3.4)^{* * * *}\end{array}$ \\
\hline Net Income/Earnings Before Taxes & NIEBT & $\begin{array}{c}0.57 \\
(2.52)^{* * * *} \\
\end{array}$ & & $\begin{array}{c}-0.18 \\
(-1.43) \\
\end{array}$ \\
\hline Annual Growth of EBIT Per Share & GEBIT & $\begin{array}{c}-0.58 \\
(-1.23) \\
\end{array}$ & $\begin{array}{l}0.005 \\
(0.02) \\
\end{array}$ & $\begin{array}{c}0.02 \\
(3.14)^{* * * *}\end{array}$ \\
\hline Retained Earnings/Total Assets & RETA & $\begin{array}{c}7.64 \\
(1.93)\end{array}{ }^{*}$ & $\begin{array}{c}-0.12 \\
(-0.11) \\
\end{array}$ & $\begin{array}{c}0.56 \\
(2.08)^{\text {*** }} \\
\end{array}$ \\
\hline Retention Ratio & RET & $\begin{array}{c}-0.92 \\
(-3.73)^{\text {**** }} \\
\end{array}$ & & $\begin{array}{c}0.001 \\
(3.24)^{* * * *}\end{array}$ \\
\hline Market Price Percentage Change & SR & & & $\begin{array}{l}-0.006 \\
(-0.95)\end{array}$ \\
\hline Net Income Percentage Change & NID & $\begin{array}{c}-1.08 \\
(-1.63)^{*}\end{array}$ & $\begin{array}{c}-0.18 \\
(-2.26)^{* *}\end{array}$ & $\begin{array}{l}-0.001 \\
(-0.55)\end{array}$ \\
\hline Dividend Payout Ratio & DPR & $\begin{array}{c}-0.18 \\
(-0.33)\end{array}$ & $\begin{array}{c}0.24 \\
(0.97)\end{array}$ & $\begin{array}{c}-0.03 \\
(-1.14)\end{array}$ \\
\hline Dividend Yield & DY & $\begin{array}{c}-0.01 \\
(-0.53)\end{array}$ & $\begin{array}{c}-0.25 \\
(-1.47) \\
\end{array}$ & $\begin{array}{c}-0.001 \\
(-3.98)^{\text {***** }} \\
\end{array}$ \\
\hline \multicolumn{2}{|c|}{$N$} & 116 & 132 & 318 \\
\hline \multicolumn{2}{|c|}{$\begin{array}{r}\text { F statistics } \\
(\text { Sig F })\end{array}$} & $24.93^{* * *}$ & $10.56^{\text {**** }}$ & $26.62^{* * *}$ \\
\hline \multicolumn{2}{|c|}{$\bar{R}^{2}$} & 0.88 & 0.70 & 0.76 \\
\hline \multicolumn{2}{|c|}{ D-W test } & $1.95^{\text {**** }}$ & $2.02^{* * * *}$ & $1.73^{* * * *}$ \\
\hline \multicolumn{2}{|c|}{ Theil Inequality Coefficient } & 0.10 & 0.14 & 0.13 \\
\hline
\end{tabular}

$* * * * \mathrm{D}-\mathrm{W}$ test significart at $2 \%$ two - sided level of significance

\footnotetext{
*** Significant at the level $1 \%$

** Significant at the level $5 \%$

*Significant at the level $10 \%$
}

Regarding the speed of adjustment, the results show that the financial ratios examined help adjust the MB ratio to a target level, where all coefficients of (Market - to - Book) $)_{\mathrm{t}-1}$ are positive and statistically significant. The financial ratios help the low MB firms the most since this level is associated with the highest speed of adjustment (0.62), followed by the high MB firms (0.25), then the medium MB firms (0.18).

As for the high MB firms, the statistically significant ratios present five ratio categories (Solvency, Assets Efficiency, Expense Control, Leverage, and Profitability). The number of profitability-related ratios is more than those ratios of the other categories. What is noticeable here is the negative coefficient of number of profitability variables, 
e.g., RONW, EBITS, EBITG, RET, and NID. This indicates that firm's profitability is not regarded by investors as a determinant of MB. The positive and statistically significant profitability-related variables are the CFPS and PE ratios. The positive relationship with MB ratio is expected as long as they are price-related. The CASHR as a solvency measure is positive and statistically significant. This is another evidence on the investors' short-term orientation as reported in table (1). What come against expectations are the negative and statistically significant coefficients of assets efficiency-related ratios, e.g., INVR and WCCF. This indicates that, for the high MB firms, the investors do not regard the elements related to firm's operations. Nevertheless, the general concern about the relationship between assets and returns is shown by the positive and statistically significant coefficient of the IE. The positive and statistically significant coefficient of TES indicates what is stated in the literature of marketing that regards the expenses/sales ratio as a capital investment. The two ratios of AE and STDTD are positive and statistically significant showing the investors' orientations toward short-term debt financing. The investors concern toward the firm's debt service capacity is shown by the positive and statistically significant TIE. Nevertheless, the negative coefficient of the same ratio using the cash flow measure CFI is not expected and could be due to data discrepancies.

As for the medium MB firms, the statistically significant ratios present four ratio categories (Solvency, Assets Efficiency, Leverage, and Profitability). As in the case of the high MB firms, the number of profitabilityrelated ratios is more than those ratios of the other categories. In this MB level, investors do not regard firm's profitability as a determinant of MB. This is shown by the negative and statistically significant coefficients of EBITS and NID. The other statistically significant profitability-related ratios are positive. These are CFPS, PCF, and MVA. This is an expected result since these ratios are price-related. The solvency-related ratios present somewhat contradictory results. The coefficients of QR and CRTE are negative and statistically significant, while the coefficient of NWCTA is positive and statistically significant. Taking into account the possibility of data discrepancies, the positive relationship could be dominating, thus indicating that the investors regard liquidity as a determinant of MB. This result is supported by the results reported in table (1) where the coefficients of short-term items are positive and statistically significant. The only statistically significant asset efficiency-related ratio is INVR, and, as in the case of high MB firms, the negative relationship indicates that the investors do not regard the elements related to firm's operations. As for the leverage category, the coefficient of NII is positive and statistically significant, which indicates the investors concern about firm's debt service ability.

As for the low MB firms, the statistically significant ratios present the six ratio categories (Solvency, Assets Efficiency, Expense Control, Leverage, Profitability, and Dividend Information). The dominant ratios are those related to profitability, asset efficiency, and solvency respectively. A general trend of investors' preference toward liquidity is shown by the positive and statistically significant coefficients of CASHR and CRTE. The negative and statistically significant coefficient of the interval measure IM is not expected. Regarding the ratios of assets efficiency, the signs are indicative. Four out of the five assets efficiency-related ratios have positive and statistically significant coefficients. These ratios are TAT, FAT, AG and SG. These results are supported by the results shown in the balance sheet items in table (1), where the coefficient of long-term investment in positive and statistically significant for the low MB firms. This is an indication to the investors' concern about long-term rather than the short-term assets. This conclusion is supported by the negative and statistically significant coefficient of WCCF where it is calculated using the components of working capital. The expenses control-related ratio OEGM is positive and statistically significant, which gives the same conclusion stated for the high and medium MB firms that the operating expenses are regarded as a capital investment. Regarding leverage-related coefficients, the coefficient of NWTD is negative and statistically significant, which indicates that the investors have a significant concern about the firm's capital structure. It is not possible to reach a conclusive explanation regarding the effects of capital structure since the other leverage-related ratios are not statistically significant. ${ }^{5}$ Nevertheless, the positive and statistically significant two retained earningsrelated coefficients (RETA and RET) could help reach an implicit explanation that the investors favor equity financing over debt financing. The other profitability-related coefficients (IB, MVA, EBITG) are positive and statistically significant, thus giving the indication that the investors are quite concerned with the overall profitability.

\footnotetext{
${ }^{5}$ NWTD is the ratio of Net Worth/Total Debt. This ratio could be increased by many ways such as (a) increasing equity, (b) decreasing total debt, (c) increasing equity by a percentage greater than the percentage of increasing debt, (d) decreasing equity by a percentage less than the percentage of decreasing total debt. This is the reason why a conclusive answer cannot be reached unless other leverage-related ratios give support.
} 
The coefficient of EBITS is an exception to that overall concern, since its sign is negative and statistically significant. It is noticeable that this coefficient is negative and statistically significant for the three levels of MB. While it could be explained as an indication to the investors' general unconcern about profitability in the two cases of high and medium MB firms, it must not be in the case of the low MB firms where all the other statistically significant coefficients are positive. This could be due to some data discrepancies. The last statistically significant coefficient is the coefficient of dividend yield (DY), where its negative sign is an indication that dividends have a reverse effect on firm's market value. The same negative sign is reported for the high and medium MB levels except that they are not statistically significant.

\section{Robustness of the Estimates (Sensitivity Analysis}

The sensitivity analysis focuses on the variables that refer to the speed of adjusting shareholder value to a target level $\left[\left(\log _{10} M B\right)_{t-1}\right.$ and $\mathbf{M B}_{\mathbf{t}-\mathbf{1}}$ ] in the partial adjustment model. These variables show the extent to which shareholder value adjusts to a target level $\left[\left(\log _{10} \mathbf{M B}\right)_{\mathbf{t}}\right.$ and $\left.\mathbf{M B}_{\mathbf{t}}\right]$ according to the content of financial information included in the balance sheet, income statement and financial ratios. Table 4 summaries the results of the sensitivity analysis and tables (A), (B), (C) in the appendix include the details of the sensitivity analysis.

Table 4: Summary Of The Robustness Of Informativeness Of Fundamental Analysis And Shareholder Value

\begin{tabular}{|c|c|c|c|c|}
\hline \multirow{2}{*}{ Types of Financial Information } & \multirow{2}{*}{$\begin{array}{c}M \text { Variables } \\
\text { (Speed of } \\
\text { Adjustment) }\end{array}$} & \multicolumn{3}{|c|}{ Shareholder Value Classes } \\
\hline & & High & Medium & Low \\
\hline Balance Sheet-related information & $\left(\log _{10} \mathrm{MB}\right)_{\mathrm{t}-1}$ & Fragile & Fragile & Fragile \\
\hline Income Statement-related Information & $\left(\log _{10} \mathrm{MB}\right)_{\mathrm{t}-1}$ & Robust & Robust & Robust \\
\hline Financial Ratios-related Information & $\mathbf{M B}_{\mathrm{t}-1}$ & Robust & Fragile & Robust \\
\hline
\end{tabular}

The results of the sensitivity analysis show a considerable degree of consistency. As for the balance sheet information content, the estimates of the speed of adjusting $\left(\log _{10} \mathrm{MB}\right)_{\mathrm{t}-1}$ shareholder value are fragile at the three levels. That is, these estimates will vary (not stable) according to the variations in the items related to sources and uses of financing. This means that the balance sheet items are not informative to the shareholders. Nevertheless, as for the income statement information content, the estimates of the speed of adjusting $\left(\log _{10} \mathrm{MB}\right)_{\mathrm{t}-1}$ shareholder value are robust at the three levels. That is, these estimates will not vary (stable) according to the variations in the items related to operating and financing activities. This means that the income statement items are quite informative to the shareholders. As for the financial ratios-related information, the estimates of the speed of adjusting $(\mathbf{M B})_{\mathbf{t}-\mathbf{1}}$ shareholder value are robust at the high and low classes only. That is, the financial ratios (as a form of co-integrated financial information) are quite informative to the high and low shareholder value classes, while is not that informative to the medium class. That is, for these two classes, the shareholder value adjusts in a stable manner to a target value even with changes in the firms' five categories of financial performance.

\section{CONCLUSION}

The results of this study provide evidence that the fundamental analysis is informative to firms' shareholders. This conclusion is summarized in Table 5. 
Table 5: Summary Of The Transparency Of The Content Of Financial Statement Information

\begin{tabular}{|c|c|c|c|c|}
\hline Criterion & Level & $\begin{array}{c}\text { Speed of } \\
\text { Adjustment }\end{array}$ & $\bar{R}^{2}$ & $\begin{array}{c}\text { Theil Inequality } \\
\text { Coefficient }\end{array}$ \\
\hline \multirow{12}{*}{$\begin{array}{c}\text { MB ratio } \\
\text { (Value Creation) }\end{array}$} & High & \multirow[b]{2}{*}{$0.39^{* * *}$} & \multirow[b]{2}{*}{0.34} & \multirow[b]{2}{*}{0.33} \\
\hline & Balance Sheet & & & \\
\hline & Income Statement & $0.35^{\text {*** }}$ & 0.40 & 0.29 \\
\hline & Financial Ratios & $0.25^{* * * *}$ & 0.88 & 0.10 \\
\hline & Medium & \multirow[b]{2}{*}{0.0001} & \multirow[b]{2}{*}{0.99} & \multirow[b]{2}{*}{0.001} \\
\hline & Balance Sheet & & & \\
\hline & Income Statement & $0.42^{* * *}$ & 0.57 & 0.21 \\
\hline & Financial Ratios & $0.18^{* * *}$ & 0.70 & 0.14 \\
\hline & Low & \multirow[b]{2}{*}{$0.008^{* * *}$} & \multirow[b]{2}{*}{0.99} & \multirow[b]{2}{*}{0.02} \\
\hline & Balance Sheet & & & \\
\hline & Income Statement & $0.80^{\text {*** }}$ & 0.84 & 0.20 \\
\hline & Financial Ratios & $0.62^{* * * *}$ & 0.76 & 0.13 \\
\hline
\end{tabular}

$* * *$ Significant at the level $1 \%$

$a$ The lower the coefficient, the higher the prediction power

The three types of financial information examined in this study (balance sheet-related, income statementrelated, and financial ratios-related information) explain substantial part of the market-to-book ratio. According to the results of this study, we can conclude that:

1. The balance sheet items for the medium and low MB firms are quite informative as the explanatory power of the regression equations is extremely high (adjusted $R^{2}=0.99$ ), indicating the clarity of the effects of the balance sheet item on firm's MB ratio. That is, the information content of the balance sheet items is more obvious for medium and low MB firms than for the high MB firms. This conclusion is expected since investors in medium and low MB firms are expected to be more concerned with the financial health of their investments. Obviously, this concern is extended to include the raw items in the balance sheet.

2. The income statement items for the low MB firms are relatively more informative to the investors than in the case of the medium and high MB firms. This conclusion is expected since investors in the low MB firms should relatively very much concerned with changes in the income statement items that could affect the worthiness of their investment. In comparison to the information content provided by the balance sheet items, we can conclude that the income statement items are more informative than the balance sheet items since the coefficients of speed of adjustment in the income statement items are greater than those for the balance sheet items.

3. The financial ratios are relatively more informative for the high MB firms than for the medium and low MB firms. The results reported in tables 1,2 , and 3 indicate that:

A. In the three levels of MB firms, investors are concerned with the short-term horizon represented by such items as cash, short-term investments and short-term financing.

B. As for the low MB firms, the investors are concerned with the long-term horizon as well represented by such items as long-term investments and assets efficiency. Also investors do not appreciate equity financing since those firms are categorized with low or medium MB ratio.

C. As for the high and low MB firms, the operating and total expenses are regarded as a capital investment that supports sales activities as stated in the literature of marketing.

D. As for the high MB firms, the trend is to finance operations using equity rather than debt financing.

E. As the MB is getting lower, the investors become more concerned with the firm's earnings power. Nevertheless, profitability affects low MB firms only rather than high and medium firms. 
F. As for the high and medium MB firms, investors do not regard the elements related to firm's operations.

G. In the low MB firms, investors are concerned with the effects of capital structure of firm's value although the results in table (3) show that dividends have a reverse effect on firm's market value.

Finally a conclusion could be reached regarding the measurement of financial information from the financial statement that the 'ratio' form is quite as indicative as the raw items in firm's balance sheet and income statements with the exception of the high MB firms where the explanatory power (adjusted $R^{2}$ ) of the balance sheet and income statement is not as high as for the medium and low MB firms.

\section{APPENDIX}

Table A: Sensitivity Analysis for Informativeness of Balance Sheet Items and Shareholder Value [Dependent Variable: $\left.\left(\log _{10} \mathbf{M B}\right)\right]^{6}$

\begin{tabular}{|c|c|c|c|c|c|c|c|c|c|}
\hline $\begin{array}{l}\text { Shareholder } \\
\text { Value Classes }\end{array}$ & $\begin{array}{c}M \\
\text { Variables } \\
\text { (MB speed of } \\
\text { adjustment) }\end{array}$ & \multicolumn{2}{|c|}{$\beta$} & SE & $t$ & $\mathbf{N}$ & $\bar{R}^{2}$ & Other Variables & $\begin{array}{l}\text { Robust/ } \\
\text { Fragile }\end{array}$ \\
\hline \multirow{3}{*}{ High MB } & \multirow{3}{*}{$\left(\log _{10} \mathrm{MB}\right)_{\mathrm{t}-1}$} & High & 0.003 & $\begin{array}{c}0.00 \\
3\end{array}$ & - & 102 & 0.99 & $\begin{array}{l}\log _{10} \text { TCA } \log _{10} \text { NFA } \\
\log _{10} \text { TCL }, \log _{10} \text { LTD }\end{array}$ & \multirow{3}{*}{ Fragile } \\
\hline & & Base & -0.007 & $\begin{array}{c}0.00 \\
3\end{array}$ & - & 102 & 0.99 & - & \\
\hline & & Low & -0.015 & $\begin{array}{c}0.00 \\
3\end{array}$ & $\begin{array}{c}- \\
1.73\end{array}$ & 102 & 0.99 & $\log _{10} T C A, \log _{10} \mathrm{NFA}$ & \\
\hline & & High & 0.0739 & $\begin{array}{c}0.02 \\
3\end{array}$ & 1.12 & 131 & 0.93 & $\begin{array}{c}\log _{10} \mathrm{TCA}, \log _{10} \mathrm{TCL} \\
\log _{10} \mathrm{TSE}\end{array}$ & \\
\hline Medium MB & $\left(\log _{10} \mathrm{MB}\right)_{t-1}$ & Base & 0.028 & $\begin{array}{c}0.02 \\
3\end{array}$ & 1.19 & 131 & 0.91 & - & Fragile \\
\hline & & Low & -0.030 & $\begin{array}{c}0.02 \\
3\end{array}$ & 0.68 & 131 & 0.93 & $\begin{array}{c}\log _{10} \mathrm{TCA}, \log _{10} \mathrm{LTD} \\
\log _{10} \mathrm{TSE}\end{array}$ & \\
\hline & & High & 0.0007 & $\begin{array}{c}0.00 \\
02\end{array}$ & 0.72 & 285 & 0.99 & $\begin{array}{l}\log _{10} \mathrm{TCA}, \log _{10} \mathrm{NFA} \\
\log _{10} \mathrm{TCL}, \log _{10} \mathrm{LTD}\end{array}$ & \\
\hline Low MB & $\left(\log _{10} \mathrm{MB}\right)_{t-1}$ & Base & 0.0007 & $\begin{array}{c}0.00 \\
02\end{array}$ & 0.28 & 285 & 0.99 & - & Fragile \\
\hline & & Low & 0.0004 & $\begin{array}{c}0.00 \\
02\end{array}$ & 0.30 & 285 & 0.99 & $\log _{10} T C A, \log _{10} T C L$ & \\
\hline
\end{tabular}

\footnotetext{
${ }^{6}$ The base $\beta$ is the estimate coefficient from the regression with the variables of interest ( $\boldsymbol{M}$ variables) and the always-included variables $(\boldsymbol{I}$ variables). When the dependent variable is the short-term debt ratio, the $I$ variables are $\log _{10}$ Cash $, \log _{10} \operatorname{Rec}, \log _{10}$ Inven, $\log _{10}$ STI , $\log _{10} C I P, \log _{10} L T I, \log _{10} A P, \log _{10} R E, \log _{10} C L S E$. The high $\beta$ is the estimate coefficient from the regression with the extreme higher bound $\left(\beta_{m}+2 \sigma\right)$. The low $\beta$ is the coefficient from the regression with the extreme lower bound. The "Other variables" are the $Z$ variables included in the base regression that produce the extreme bounds. The "Robust/Fragile" designation indicated whether the variable of interest is robust or fragile.
} 
Table B: Sensitivity Analysis for Informativeness of Income Statement Items and Shareholder Value [Dependent Variable: $\left.\left(\log _{10} \mathrm{MB}\right)\right]^{7}$

\begin{tabular}{|c|c|c|c|c|c|c|c|c|c|}
\hline $\begin{array}{l}\text { Shareholder } \\
\text { Value Classes }\end{array}$ & $\begin{array}{c}\boldsymbol{M} \\
\text { Variables } \\
\text { (MB speed of } \\
\text { adjustment) }\end{array}$ & \multicolumn{2}{|c|}{$\beta$} & SE & $t$ & $N$ & $\bar{R}^{2}$ & Other Variables & $\begin{array}{l}\text { Robust/ } \\
\text { Fragile }\end{array}$ \\
\hline \multirow{3}{*}{ High MB } & \multirow{3}{*}{$\left(\log _{10} M B\right)_{t-1}$} & High & 0.314 & 0.06 & 4.93 & 120 & 0.32 & $\log _{10} G P, \log _{10}$ EBIT & \multirow{3}{*}{ Robust } \\
\hline & & Base & 0.309 & 0.062 & 4.93 & 120 & 0.33 & - & \\
\hline & & Low & 0.182 & 0.063 & 4.89 & 120 & 0.32 & $\log _{10} \mathrm{NI}$ & \\
\hline \multirow{3}{*}{ Medium MB } & \multirow{3}{*}{$\left(\log _{10} M B\right)_{t-1}$} & High & 0.495 & 0.051 & 7.62 & 130 & 0.53 & $\log _{10} G P, \log _{10}$ EBIT & \multirow{3}{*}{ Robust } \\
\hline & & Base & 0.392 & 0.051 & 7.68 & 130 & 0.53 & - & \\
\hline & & Low & 0.382 & 0.051 & 7.4 & 130 & 0.55 & $\log _{10} E B I T, \log _{10} N I$ & \\
\hline \multirow{3}{*}{ Low MB } & \multirow{3}{*}{$\left(\log _{10} \mathrm{MB}\right)_{\mathrm{t}-1}$} & High & 0.874 & 0.03 & 20.3 & 308 & 0.84 & $\log _{10} \mathrm{NI}$ & \multirow{3}{*}{ Robust } \\
\hline & & Base & 0.796 & 0.03 & 20.4 & 308 & 0.84 & - & \\
\hline & & Low & 0.786 & 0.03 & 19.7 & 308 & 0.84 & $\log _{10} G P, \log _{10}$ EBIT, $\log _{10} N I$ & \\
\hline
\end{tabular}

Table C: Sensitivity Analysis for Informativeness of Financial Ratios and Shareholder Value (Dependent Variable: $\left.\mathrm{MB}_{\mathrm{t}}\right)^{8}$

\begin{tabular}{|c|c|c|c|c|c|c|c|c|c|}
\hline $\begin{array}{c}\text { Shareholder Value } \\
\text { Classes }\end{array}$ & $\begin{array}{c}\boldsymbol{M} \\
\text { Variables } \\
\text { (MB speed of } \\
\text { adjustment) } \\
\end{array}$ & \multicolumn{2}{|c|}{$\beta$} & SE & $t$ & $N$ & $\bar{R}^{2}$ & Other Variables & $\begin{array}{l}\text { Robust/ } \\
\text { Fragile }\end{array}$ \\
\hline \multirow{3}{*}{ High MB } & \multirow{3}{*}{$\mathbf{M B}_{t-1}$} & High & 0.627 & 0.062 & 8.02 & 118 & 0.88 & EBITS & \multirow{3}{*}{ Robust } \\
\hline & & Base & 0.486 & 0.064 & 7.57 & 118 & 0.88 & - & \\
\hline & & Low & 0.335 & 0.065 & 7.09 & 118 & 0.90 & WCCF, ES, AE & \\
\hline \multirow{3}{*}{ Medium MB } & \multirow{3}{*}{$\mathbf{M B}_{t-1}$} & High & 0.351 & 0.081 & 2.34 & 132 & 0.74 & WCCF , AE & \multirow{3}{*}{ Fragile } \\
\hline & & Base & 0.157 & 0.084 & 1.85 & 132 & 0.71 & - & \\
\hline & & Low & -0.049 & 0.083 & 1.4 & 132 & 0.72 & CashR, WCCF, ES & \\
\hline \multirow{3}{*}{ Low MB } & \multirow{3}{*}{$\mathbf{M B}_{t-1}$} & High & 0.549 & 0.044 & 10.2 & 326 & 0.70 & $\underset{\text { EBITS }}{\text { WCCF }, \text { ES , AE , }}$ & \multirow{3}{*}{ Robust } \\
\hline & & Base & 0.415 & 0.051 & 8.09 & 326 & 0.68 & - & \\
\hline & & Low & 0.308 & 0.051 & 7.98 & 326 & 0.68 & $\operatorname{Cashr}, \mathbf{E S}, \mathbf{A E}$ & \\
\hline
\end{tabular}

\footnotetext{
${ }^{7}$ The base $\beta$ is the estimate coefficient from the regression with the variables of interest ( $\boldsymbol{M}$ variables) and the always-included variables $(\boldsymbol{I}$ variables). When the dependent variable is the short-term debt ratio, the $I$ variables are $\log _{10} N S, \log _{10} C \boldsymbol{O G S}, \log _{10} S G A E, \log _{10}$ Prov, $\log _{10} T E, \log _{10}$ Invin, $\log _{10}$ Intexp $, \log _{10} O R, \log _{10} E X R, \log _{10} E X E X, \log _{10} T A X$. The high $\beta$ is the estimate coefficient from the regression with the extreme higher bound $\left(\beta_{m}+2 \sigma\right)$. The low $\beta$ is the coefficient from the regression with the extreme lower bound. The "Other variables" are the $\boldsymbol{Z}$ variables included in the base regression that produce the extreme bounds. The "Robust/Fragile" designation indicated whether the variable of interest is robust or fragile.

${ }^{8}$ The base $\beta$ is the estimate coefficient from the regression with the variables of interest $(\boldsymbol{M}$ variables) and the always-included variables $(\boldsymbol{I}$ variables). When the dependent variable is the short-term debt ratio, the $\boldsymbol{I}$ variables are INVCA, ARCA, QR, CR, TLNW, NWCTA, IM, CRTE, TAT, FAT, INVC, INVR, DINV, ART, APT, NWCT, APS, NWFA, AG, SG, COGSS, OEGM, OEA, IE, CLWC, STDR, TIE, EBITFC, CFI, NII, NWD, OL, LTDNW, FATA, RONW, ROA, CFPS, CFLTD, PE, PCF, TB, IB, MVA, NIEBT, GEBIT, REA, RET, SR, NID, DPR, DY. The high $\beta$ is the estimate coefficient from the regression with the extreme higher bound $\left(\beta_{m}+2 \sigma\right)$. The low $\beta$ is the coefficient from the regression with the extreme lower bound. The "Other variables" are the $\boldsymbol{Z}$ variables included in the base regression that produce the extreme bounds. The "Robust/Fragile" designation indicated whether the variable of interest is robust or fragile.
} 


\section{REFERENCES}

1. Beaver, W. H. and Ryan, S. G. Biased Recognition (Conservatism) and Delayed Recognition in Accounting and their Effects on the Ability of the Book-to-Market Ratio to Predict Book Returns on Equity, Working Paper, New York University, (1996).

2. Beaver, W. H. and Ryan, S. G. Biases and Lags in Book Value and their Effects on the Ability on the Bookto-Market Ratio to Predict Book Returns on Equity, Journal of Accounting Research 38, No. 1, (2000), 127 148 .

3. Billings, B. K. and Morton, R. M. Book-to-Market Components, Future Security Returns, and Errors in Expected Future Earnings, Journal of Accounting Research 39, No. 2, (2001), 197-219.

4. Brief, R. P. and Lawson, R. A. The Role of the Accounting Rate of Return in Financial Statement Analysis, The Accounting Review 67, No. 2, (1992), 411-426.

5. Fairfield, P. M. P/E, P/B and the Present Value of Future Dividends, Financial Analysts Journal 50, No. 4, (1994), 23-31.

6. $\quad$ Farrelly, G. E., Ferris, K. R., and Reichestein. R. W., Perceived Risk, Market Risk, and Accounting Determined Risk Measures, The Accounting Review 15, No. 2, (1985), 278-288.

7. Fiani \& Partners. Kompass Egypt, Financial Year Book (Cairo: Fiani \& Partners).

8. Gonedes, N. J., Evidence on the Information Content of Accounting Numbers: Accounting-based and Market-based Estimates of Systematic Risk, Journal of Financial and Quantitative Analysis 8, No. 3, (1973), 407-443.

9. Greene, William H. (2000). Econometric Analysis, $4^{\text {th }}$ edition, New Jersey: Prentice-Hall Inc.

10. Kennedy, Peter. (1998). A Guide to Econometrics, $4^{\text {th }}$ edition, Oxford:Blackwell Publishers Ltd.

11. Lakonishok, J., Shleifer, A., and Vishny, R. W., Contrarian Investment, Extrapolation, and Risk., Journal of Finance 49, No. 5, (1994), 1541-1578.

12. La Porta, R. Expectations and the Cross-Section of Stock Returns, Journal of Finance 51, No. 5, (1996), $1715-1742$.

13. Leamer, Edward E. (1983). Let's take the con out of econometrics, American Economic Review, 73: 31-43.

14. Leamer, Edward E. (1985). Sensitivity analysis would help, American Economic Review, 75: 308-313.

15. Leamer, Edward E. and Leonard, H. (1983). Reporting the fragility of regression estimates, Review of Economics and Statistics, 65:306-317.

16. Levine, R. and Renelt, D. (1992). A sensitivity analysis of cross-country growth regressions, American Economic Review, 82:942-963.

17. Penman, S. H. The Articulation of Price-Earnings Ratios and Market-to-Book Ratios and the Evaluation of Growth, Journal of Accounting Research 34, No. 2, (1996), 235-259. 